\title{
AN ANALYSIS OF THE CONTENT OF PTERIDOPHYTA SPORES IN AEROPLANKTON OF LUBLIN (2013-2014)
}

\author{
Weronika Haratym, Elżbieta Weryszko-Chmielewska, Marta Dmitruk \\ Department of Botany, University of Life Sciences in Lublin, Akademicka 15, 20-950 Lublin, Poland \\ e-mail: elzbieta.weryszko@up.lublin.pl
}

Received: 25.08.2014

\begin{abstract}
Similarly to fungal spores and pollen grains, pteridophytic spores can cause allergies in humans. Pteridophyta spore concentrations in the air of Lublin, under the conditions of central-eastern Poland, were first studied over the period 2013-2014. The volumetric method was used in this study. The research showed that that spores of ferns belonging to the following genera: Asplenium, Athyrium, Blechnum, Botrychium, Cystopteris, Dryopteris, Matteuccia, Osmunda, Polypodium and Pteridium, occur in aeroplankton. Spores were recorded in low concentrations and they occurred in a dispersed pattern during the season. They were found to be absent on some days. Among the above-mentioned genera, Dryopteris and Athyrium showed the highest content of spores in aerosol. In both years of the study (2013 and 2014), similar annual spore counts were recorded, respectively 69 and 63 . The most spores were identified in August.
\end{abstract}

Key words: aerobiology, pteridophytic spores, concentration, Lublin, central-eastern Poland

\section{INTRODUCTION}

Pteridophytic spores, similarly to pollen grains and fungal spores, are components of biological aerosol (aeroplankton) contained in the air [1,2]. Fungal spores usually rank first among bioaerosol constituents due to their highest concentrations (1000-10 $\left.000 \mathrm{~m}^{-3}\right)$, while pollen grains and fern spores can reach a similar content $\left(10-100 \mathrm{~m}^{-3}\right)$ [3].

The above-mentioned aeroplankton components are carriers of allergenic proteins which can cause allergies in humans and animals and therefore are treated as environmental pollutants $[1,3,4]$. A study conducted by allergists in Singapore showed high sensitivity of many patients to spores of six fern species, among others Asplenium nidus, Nephrolepsis auriculata, and
Pteridium aquilinum. Allergic reaction was observed in $20-34 \%$ of patients in whom skin tests were performed using extracts from particular fern species [5]. Spores of Pteridium aquilinum and several other ferns were also found to have cancerogenic properties [6].

Aerobiological research on Pteridophyta spores is carried out on a small scale in the world. Among 215 genera representing Pteridophyta, distributed mainly in the tropics and subtropics, aerobiological monitoring has identified 49, including 42 in the studies conducted in Asia [7]. In the literature, only several papers can be found which relate to the airborne spore content of Pteridophyta in Europe: in Rothamsted [8] and Edinburgh [9] (UK), in Rzeszów (Poland) [10], and in Salamanca (Spain) [11].

The morphological characteristics of pteridophytic spores of 44 species belonging to 18 genera and 13 families occurring in Poland are presented by $\mathrm{Z}$ e $\mathrm{n}$ $\mathrm{kteler}$ [12].

The aim of this study was to conduct, for the first time, monitoring of fern spore concentrations in the air of Lublin, which is located in central-eastern Poland. The investigations were carried out over a period of 3 months (June - August) during two successive years (2013-2014). The research undertaken will allow us to evaluate the degree of air pollution in $\mathrm{Lu}-$ blin by Pteridophyta spores which are an aeroplankton component; these spores can be environmental biopollutants posing a threat to human health.

\section{MATERIALS AND METHODS}

The study material consisted of airborne Pteridophyta spores trapped in Lublin - a city located in the central east part of Poland, on the northern edge of the Lublin Upland. Spore monitoring was carried out from $1^{\text {st }}$ of June to $31^{\text {st }}$ of August in 2013 and 2014. 
The investigations are conducted by the volumetric method using a Hirst - type trap, a Lanzoni VPPS 2000 sampler, placed on the flat roof of the building of the University of Life Sciences in Lublin in the central part of Lublin $\left(51^{\circ} 14^{\prime} 37^{\prime \prime} \mathrm{N}\right.$ and $\left.22^{\circ} 32^{\prime} 25^{\prime \prime} \mathrm{E}\right)$. The device is located $18 \mathrm{~m}$ above ground level (197 m a.s.l). In this trap, matter particles are aspirated together with air through a narrow orifice $(2 \times$ $14 \mathrm{~mm}$ ) at a rate of 101 per minute, which is similar to the volume of air inhaled in humans. The sampler has a circular drum driven by a clock mechanism rotating at a speed of $2 \mathrm{~mm}$ per hour. The Melinex tape is mounted on a cylinder and coated with silicone oil. Every week at the same time the tape is replaced with a new one. Subsequently, the tape is cut into $48 \mathrm{~mm}$ sections corresponding to 24 -h periods and microscope slides are prepared using glycerol-gelatine with the addition of basic fuchsin dye. The next step is to analyze the material under a light microscope at a 400-fold magnification. Spores are counted along four horizontal lines. The number of spores obtained is multiplied by a correction factor, which depends on the magnification applied, width of the field of view, and the surface area of the slide. The concentration of spores is expressed as the number of spores in $1 \mathrm{~m}^{3}$ of air.

Identification of pteridophytic spores was done based on the data contained in the publications by $\operatorname{Tr} \mathrm{y}-$ on and Lugardon [13] and by Zenkteler [12].

\section{RESULTS}

In 2013 spores of Pteridophyta belonging to 9 taxa (eight ferns and Equisetum) were identified in the aerobiological slides analyzed (Table 1). Images of the studied fern genera viewed under a light microscope are shown in Figure $1(\mathrm{a}-\mathrm{O})$. Spores of Asplenium, Athyrium, Blechnum, Botrychium, Cystopteris, Dryopteris, Matteuccia and Polypodium were identified during the monitoring.

In 2014 spores of 8 fern genera were also distinguished, but among them there were two other genera (Osmunda, Pteridium) than in the previous year (Table 2). On the other hand, spores of Blechnum and Cystopteris were not found.

Each year over the 3-month study period during the growing season, the highest number of fern spores per $1 \mathrm{~m}^{3}$ of air was recorded in August. July was the next month that was also abundant in airborne spores of some Pteridophyta taxa (Table 1,2). In both years, similar Pteridophyta spore counts were recorded (69 and 63 spores $\mathrm{m}^{-3}$ ).

In 2013 the maximum concentrations recorded during the season of airborne Pteridophyta spores were 3 spores $\mathrm{m}^{-3}$, while in 2014 they were 5 spores $\mathrm{m}^{-3}$ (Fig. $2,3)$.

The most spores identified in the slides belonged to the genera Dryopteris (on average 32) and Athyrium (on average 18). In both years, the maximum Dryopteris spore concentrations were recorded in the third 10-day period of June (Fig. 4). Spores of this taxon were not found in the air on some days during the investigated seasons. On the other hand, the Athyrium spore season began at the end of the second 10-day period of July (2014) or in the third 10-day period of this month (2013) (Fig. 5). The highest concentrations of spores of this genus were observed in different 10-day periods of August in both years.

Table 1

Monthly incidence of airborne pteridophytic spores in Lublin in 2013 (number of spores $\times \mathrm{m}^{-3}$ )

\begin{tabular}{|c|c|c|c|c|}
\hline \multirow{2}{*}{ Genera } & \multicolumn{3}{|c|}{ Months with total spore count } & \multirow{2}{*}{ Total count } \\
\hline & June & July & August & \\
\hline Asplenium sp & 0 & 1 & 3 & 4 \\
\hline Athyrium sp. & 0 & 3 & 14 & 17 \\
\hline Blechnum sp. & 0 & 0 & 1 & 1 \\
\hline Botrychium sp. & 0 & 3 & 0 & 3 \\
\hline Cystopteris sp. & 0 & 0 & 1 & 1 \\
\hline Dryopteris sp. & 11 & 19 & 4 & 34 \\
\hline Equisetum sp. & 2 & 0 & 1 & 3 \\
\hline Matteuccia sp. & 0 & 0 & 3 & 3 \\
\hline Polypodium sp. & 0 & 0 & 1 & 1 \\
\hline Unidentified types & 0 & 0 & 2 & 2 \\
\hline Monthly total & 13 & 26 & 30 & 69 \\
\hline
\end{tabular}



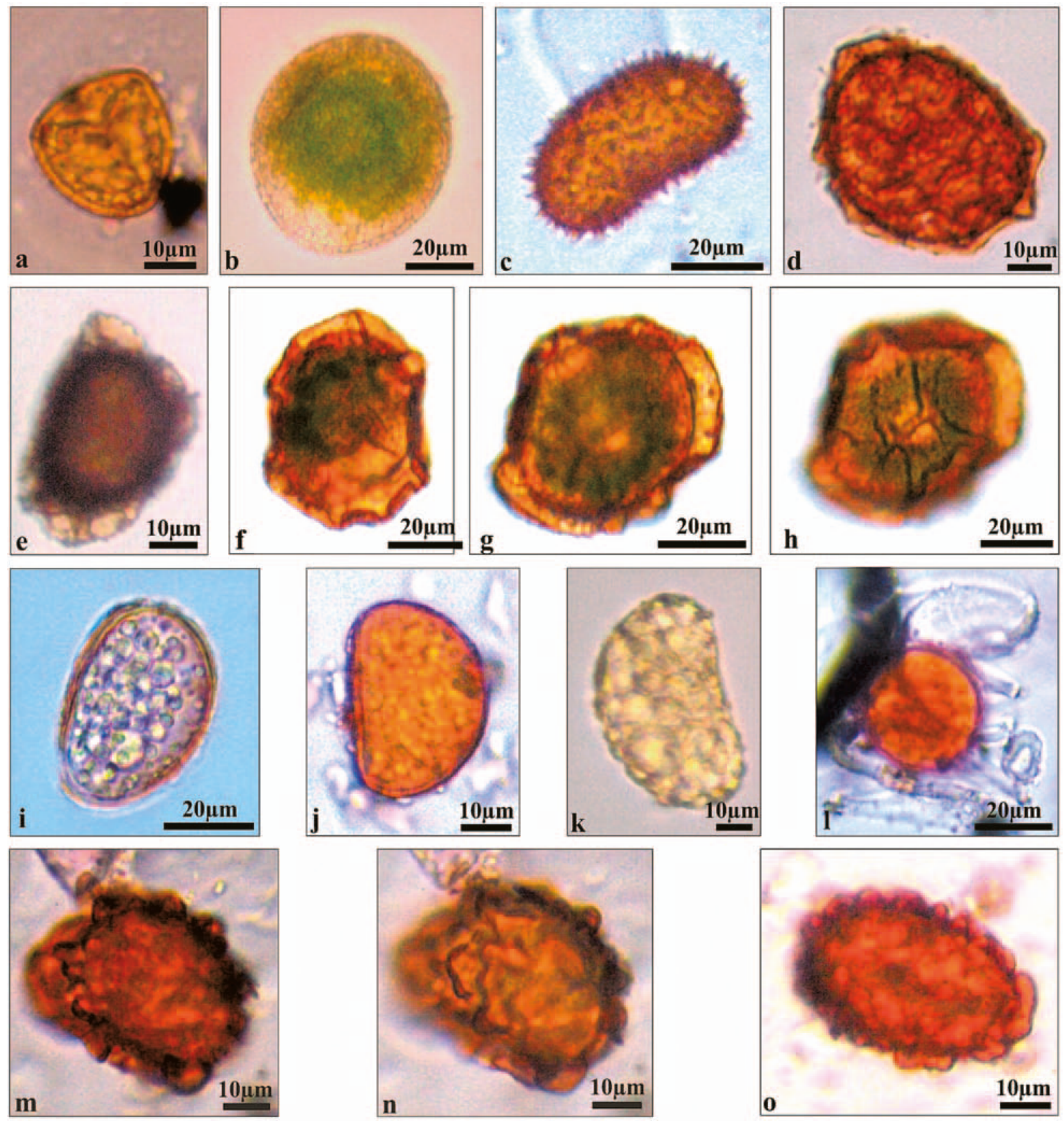

Fig. 1. Pteridophyta spores occuring in the air of Lublin from June to August 2013 and 2014 (light microscopy).

a-Botrychium sp.

$\mathrm{b}-$ Osmunda sp.

$\mathrm{c}-$ Cystopteris sp.

d,e - Asplenium sp.

$\mathrm{f}-\mathrm{h}-$ Matteuccia $\mathrm{sp}$.

$\mathrm{i}-$ Blechnum sp.

$\mathrm{j}-$ Athyrium sp.

$\mathrm{k}$ - Polypodium $\mathrm{sp}$.

1 - Equisetum sp.

$\mathrm{m}-\mathrm{o}-$ Dryopteris sp. 
Table 2

Monthly incidence of airborne pteridophytic spores in Lublin in 2014 (number of spores $/ \mathrm{m}^{3}$ )

\begin{tabular}{|c|c|c|c|c|}
\hline \multirow{2}{*}{ Genera } & \multicolumn{3}{|c|}{ Months with total spore count } & \multirow{2}{*}{ Total count } \\
\hline & June & July & August & \\
\hline Asplenium $\mathrm{sp}$ & 1 & 2 & 0 & 3 \\
\hline Athyrium sp. & 1 & 5 & 13 & 19 \\
\hline Blechnum sp. & 0 & 0 & 0 & 0 \\
\hline Botrychium sp. & 1 & 1 & 0 & 2 \\
\hline Cystopteris sp. & 0 & 0 & 0 & 0 \\
\hline Dryopteris sp. & 8 & 10 & 11 & 29 \\
\hline Equisetum sp. & 0 & 2 & 0 & 2 \\
\hline Matteuccia sp. & 1 & 0 & 1 & 2 \\
\hline Osmunda sp. & 0 & 1 & 1 & 2 \\
\hline Polypodium sp. & 0 & 1 & 0 & 1 \\
\hline Pteridium sp. & 0 & 0 & 1 & 1 \\
\hline Unidentified types & 2 & 0 & 0 & 2 \\
\hline Monthly total & 14 & 22 & 27 & 63 \\
\hline
\end{tabular}

\section{3}



Fig. 2. The Pteridophyta spore season dynamics in Lublin 2013.

\section{4}

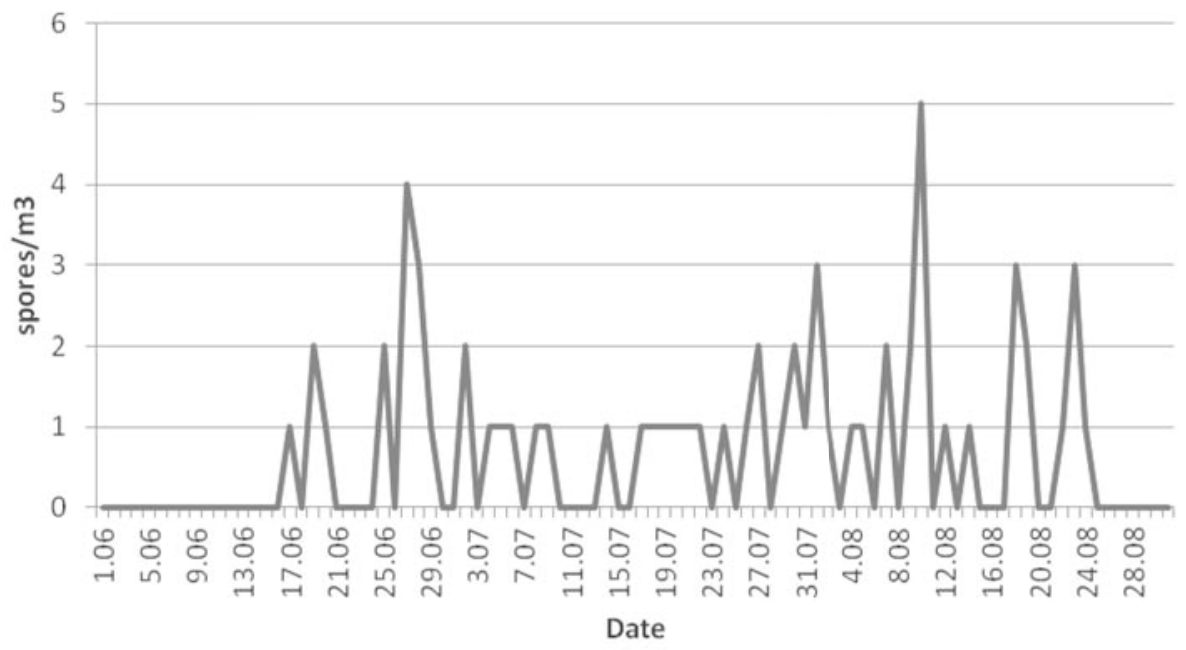

Fig. 3. The Pteridophyta spore season dynamics in Lublin 2014. 

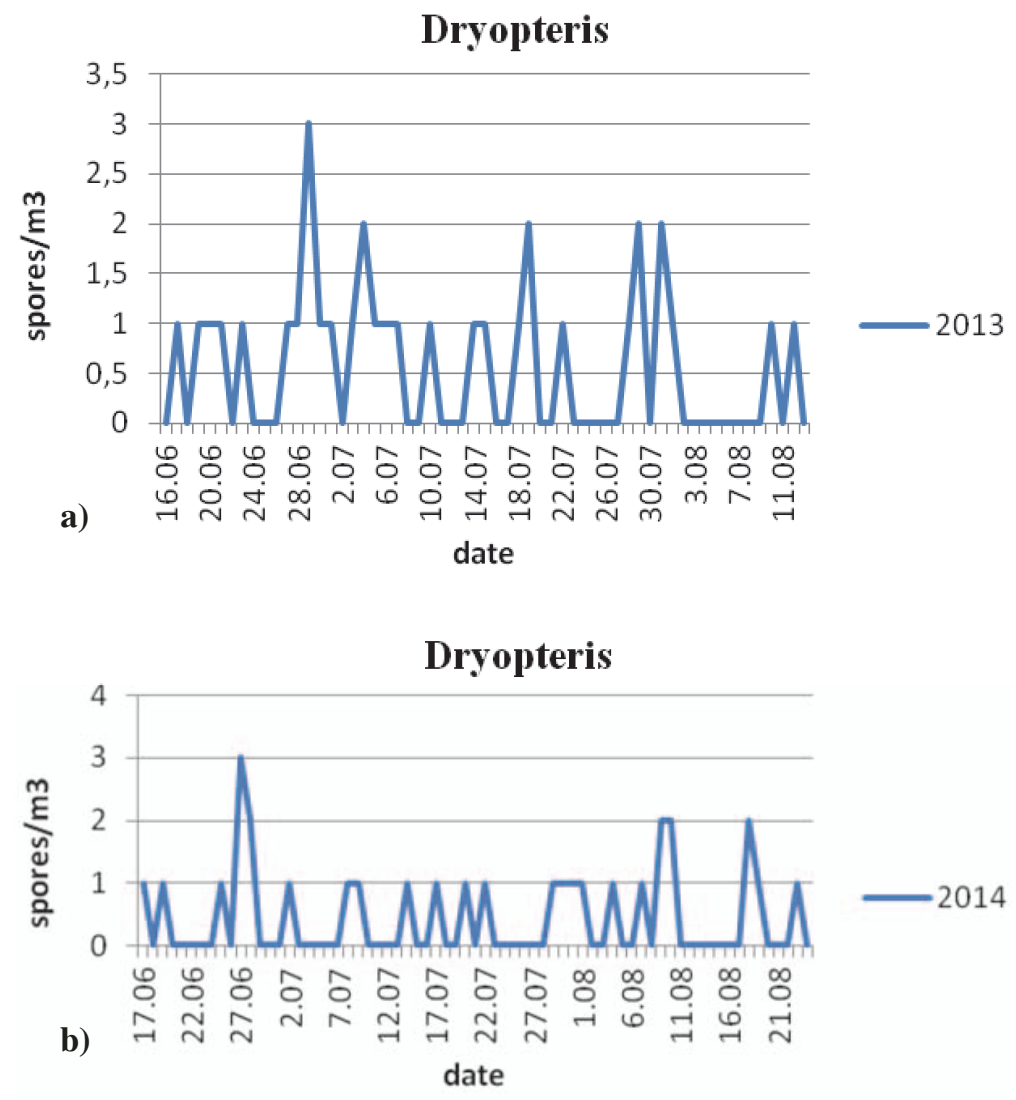

Fig. 4. Daily Dryopteris spore concentrations in Lublin, a - 2013, b - 2014
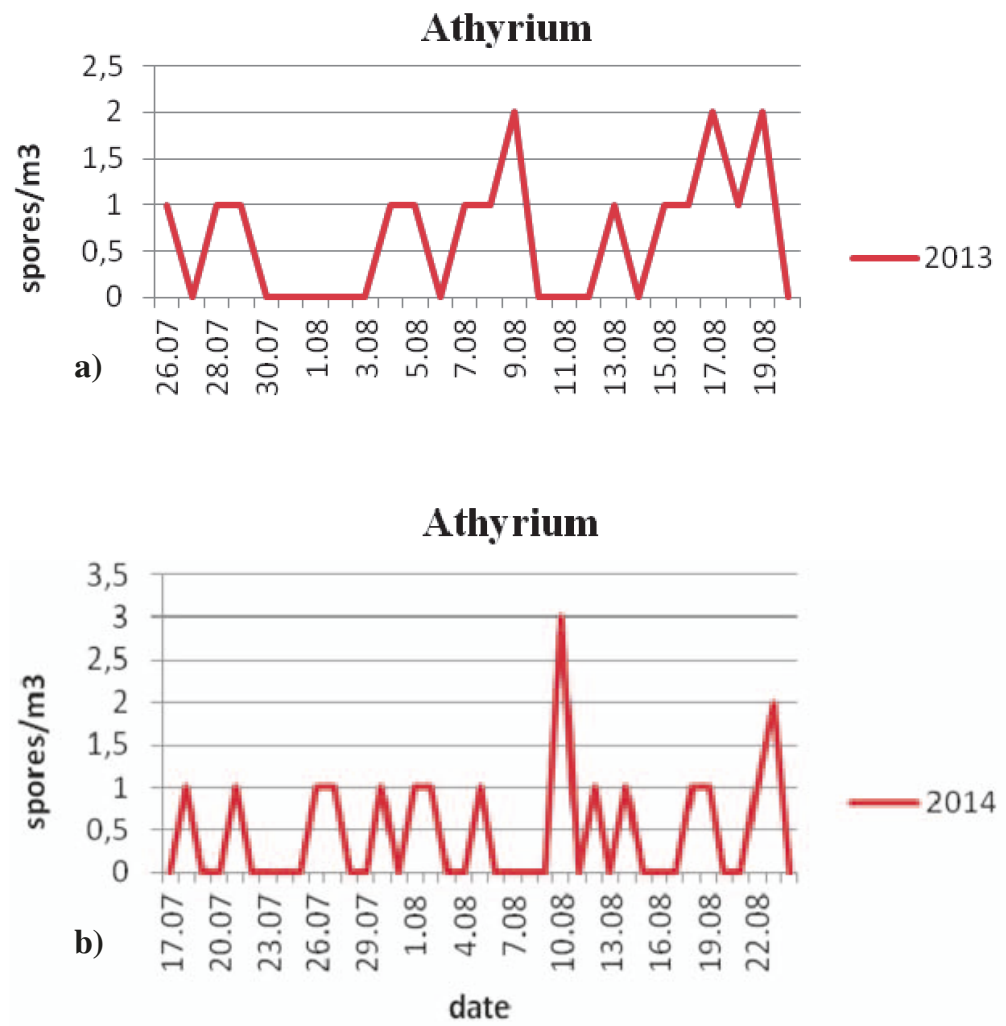

Fig. 5. Daily Athyrium concentrations in Lublin, a - 2013, b - 2014. 


\section{DISCUSSION}

Most studies involving monitoring of pteridophytic spores in aeroplankton relate to tropical species and such spores have been recorded, among others, in South America [14], Asia [15,16], and Africa [17].

The annual counts of Pteridophyta spores that we recorded in Lublin over the 2-year study period $(69,63)$ were similar to the annual sums of Polypodiaceae spores recorded in Rzeszów by Ka s pr z y k [10] in 1999 and 2000, which were respectively 59 and 82.

The research on concentrations of airborne Pteridium aquilinum spores shows that the distance of the spore trap from clumps of spore-releasing plants and the height at which it is installed are of great importance. In their study conducted in Rothamstad in 1990 and 1991, Lacey and McCartney [8] located a spore trap in a field at a distance of about $20 \mathrm{~cm}$ from a clump of Pteridium aquilinum fronds. On some days of plant growth, they found the daily mean concentrations to be very high, since they exceeded 1.750 spores $\mathrm{m}^{-3}$.

However, an aerobiological study of bracken spores which was carried out under urban conditions of Edinburgh by C a u l t o n et al. [9] over the period 1988-1997 produced results that differed significantly from the data reported by the previous authors. In this case, the spore sampler was installed at a height of 21 $\mathrm{m}$ above ground level at a distance of about $1.6 \mathrm{~km}$ from the nearest sporing stand. The maximum concentration of Pteridium aquilinum spores recorded under these conditions in 1989, having a much higher spore count than in the other years, was only 4 . The low concentrations of pteridophytic spores demonstrated in Lublin might have been associated with the location of the spore sampler on the roof of a high building around which no stands of Pteridiophyta were observed within a radius of $1 \mathrm{~km}$.

Our study reveals that the pattern of the curves depicting the fern sporulation seasons in Lublin differs between 2013 and 2014. Other authors conducting research in Europe have also found that the length and timing of the sporing period vary between years $[8,9]$.

\section{CONCLUSIONS}

1. Spores from 10 fern genera were recorded in aeroplankton of Lublin and most of them belonged to Dryopteris and Athyrium.

2. In both years of the study the most Pteridophyta spores in the air of Lublin were identified in August.

\section{Acknowledgements}

This research was supported by Ministry of Science and Higher Education of Poland as a part of the activities of the Department of Botany, University of Life Sciences in Lublin.

\section{Authors' contribution}

Concept of study: EW-C; microscopical analysis: WH, EW-C, MD; writing of manuscript: WH, EW-C; photographs: WH, MD.

\section{REFERENCES}

1. Burge HA, Rogers CA. Outdoor allergens. Environtmental Health Perspectives 2000. 108 (Sup 4): 653-659. http://dx.doi.org/10.2307/3454401

2. Weryszko-Chmielewska E. Aerobiologia. WAR Lublin. Lublin, 2007 (in Polish)

3. Després VR, Huffman JA, Burrows SM, Hoose C, Safatov AS, Buryak GA, FröhlichNowoisky J, Elbert W, Andreae MO.PöschlU. \& Jaenicke R. Primary biological aerosol particles in the atmosphere: a review. Tellus 2012 64B: 15598. http://dx.doi. org/10.3402/tellusb.v64i0.15598

4. Singh J, Devi S. New Approach to the Study of Allergenic Fern Sporoderm. Prod. Indian Natn. Sci. Acad. 1990. B56 No. 3: 299-304.

5. Chew FT, Lim SH, Shang HS, Dahlia MD, Goh DY, Lee BW, Tan HT, Tan TK. Evaluation of the allergenicity of tropical pollen and airborne spores in Singapore. Allergy 2000; 55, 340-347. http://dx.doi.org/10. 1034/j.1398-9995.2000.00308.x

6. Simán SE., Povey AC, Ward TH. Margison G.P., Sheffield E. Fern spore extracts can damage DNA. Br J Cancer. 2000 Jul;83(1):69-73. http://dx.doi.org/ 10.1054/bjoc.2000.1204

7. Rodríguez de la Cruz D., Sánchez-Reyes E., Sánchez-Sánchez J. Aerobiology of Pteridophyta Spores: Preliminary Results and Applications [In:] Working with Ferns 2010, pp 271-281. http://dx.doi.org/10. 1007/978-1-4419-7162-3_20

8. Lacey ME, McCartney HA. Measurements of airborne concentrations of spores of bracken Pteridium aquilinum. Grana. 1994; 33(2): 91-93. http://dx.doi.org/ 10.1080/00173139409427838

9. Caulton E, Keddie S, Carmichael R, Sales J. A ten year study of the incidence of spores of bracken, (Pteridium aquilinum (L.) Kuhn.) in an urban rooftop air stream in south east Scotland. Aerobiologia. 2000; 16: 2933. http://dx.doi.org/10.1023/A:1007674431125

10. Kasprzyk I. Airborne pollen of entomophilous plants and spores of pteridophytes in Rzeszów and its environs (SE Poland). Aerobiologia. 2004, 20 (4): 217-222. http://dx.doi. org/10.1007/s10453-004-1185-0

11. Rodríguez de la Cruz D, Sánchez-Reyes E, Sánchez-Sánchez J. Effects of meteorological factors on airborne bracken (Pteridium aquilinum (L.) Kuhn.) spores in Salamanca (middle-west Spain). International Journal of Biometeorology 03/2009; 53(3):231-7. http://dx.doi. org/10.1007/s00484-009-0208-5 
12. Zenkteler E. Morphology and peculiar features of spores of fern species occurring in Poland. Acta Agrobot. 2012; 65(2): 3-10. http://dx.doi.org/http://dx.doi.org/10.5586/aa. 2012.053

13. Tryon AF, Lugardon B. Spores of the Pteridophyta: surface, wall structure, and diversity based on electron microscope studies. New York : Springer-Verlag. 1990.

14. Simabukuro EA, Esteves LM, Felippe GM. Fern spore rain collected at two different heights at Moji Guaçu (Săo Paulo, Brazil). Fern Gaz. 2000; 16(3): 147-166.

15. Singh YJ, Devi S. Pteridophyte Aerospora of India. Grana. 1988; 27: 229-238. http://dx.doi.org/10.1080/ 00173138809428930

16. Hoss a in MS, Pas ha MK. Airborne fungal and pteridophytic spores in Chittagong University Campus, Chittagong. J. Asiat. Soc. Bangladesh, 2012; Sci. 38(1): 119-124.

17. La Serna I and Domínguez MD. Pólenes y esporas aerovagantes en Canarias: Incidencia en alergias. Colección Materiales Didácticos Universitarios, Serie Botánica1, SPULL, Tenerife. 2003 (in Spanish)

\section{Analiza zawartości zarodników Pteridophyta w aeroplanktonie Lublina (2013-2014)}

\author{
Streszczenie
}

Podobnie jak zarodniki grzybów i ziarna pyłku, spory paprotników mogą wywoływać alergie u ludzi. W latach 2013-2014 po raz pierwszy badano koncentracje zarodników Pteridophyta w powietrzu Lublina, w warunkach środkowo - wschodniej Polski. Do badań wykorzystano metodę wolumetryczną. Wykazano, że w aeroplanktonie występują zarodniki paproci należące do rodzajów: Asplenium, Athyrium, Blechnum, Botrychium, Cystopteris, Dryopteris, Matteuccia, Osmunda, Polypodium i Pteridium. Zarodniki rejestrowano w niskich stężeniach, w sezonie występowały w sposób rozproszony. W niektórych dniach stwierdzono ich brak. Spośród wymienionych rodzajów największa zawartość zarodników w aerozolu dotyczyła Dryopteris i Athyrium. W obu latach badań zanotowano zbliżone roczne sumy zarodników, które wynosiły kolejno 69 i 63. Najwięcej zarodników zidentyfikowano w sierpniu.

Handling Editor: Elżbieta Pogroszewska

This is an Open Access digital version of the article distributed under the terms of the Creative Commons Attribution 3.0 License (creativecommons.org/licenses/by/3.0/), which permits redistribution, commercial and non-commercial, provided that the article is properly cited.

CThe Author(s) 2014 Published by Polish Botanical Society 